\title{
Prevalence of Rheumatoid Arthritis and Spondyloarthritis in Turkey: A Nationwide Study
}

\begin{abstract}
Tiraje TUNCER, ${ }^{1}$ Erdal GILGİL, ${ }^{2}$ Cahit KAÇAR,,${ }^{1}$ Yeşim KURTAİş, ${ }^{3}$ Şehim KUTLAY, ${ }^{3}$ Bülent BÜTÜN, ${ }^{1}$ Peyman YALÇIN,${ }^{3}$ Ülkü AKARIRMAK, ${ }^{4}$ Lale ALTAN, Füsun ARDIÇ, ${ }^{6}$ Özge ARDIÇOĞLU, ${ }^{7}$ Zuhal ALTAY, ${ }^{8}$ Ferhan CANTÜRK, ${ }^{9}$ Lale CERRAHOĞLU, ${ }^{10}$ Remzi ÇEVIK,,${ }^{11}$ Hüseyin DEMİR, ${ }^{12}$ Berrin DURMAZ, ${ }^{13}$ Nigar DURSUN, ${ }^{14}$ Tuncay DURUÖZ,,${ }^{15}$ Canan ERDOĞAN, ${ }^{16}$ Deniz EVCIK,,${ }^{17}$ Savaş GÜRSOY, ${ }^{18}$ Sami HIZZMETLİ, ${ }^{19}$ Ece KAPTANOĞLU, ${ }^{19}$ Önder KAYHAN, ${ }^{15}$ Mehmet KIRNAP, ${ }^{12}$ Siranuş KOKINO, ${ }^{20}$ Erkan KOZANOĞLU, ${ }^{21}$ Banu KURAN, ${ }^{22}$ Kemal NAS, ${ }^{23}$ Sema ÖNCEL, ${ }^{24}$ Dilşad SINDEL,,${ }^{25}$ Sevim ORKUN, ${ }^{26}$ Tunay SARPEL,,${ }^{21}$ Serpil SAVAŞ,,${ }^{27}$ Ömer Faruk ŞENDUR, ${ }^{28}$ Kazım ŞENEL, ${ }^{29}$ Hatice UĞURLU, ${ }^{30}$ Kaan UZUNCA,,${ }^{31}$ İbrahim TEKEOĞLU, ${ }^{23}$ Francis GUILLEMIN ${ }^{32}$
\end{abstract}

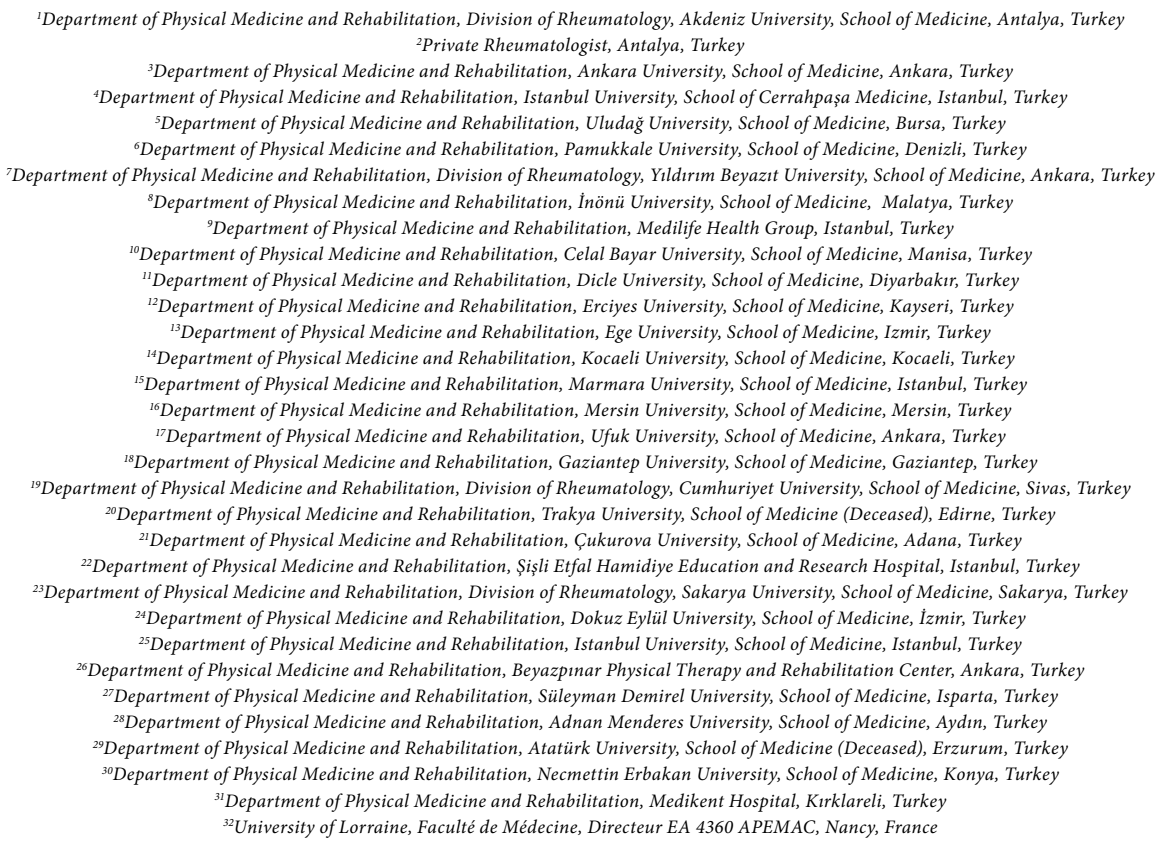

\begin{abstract}
Objectives: This study aims to estimate the prevalence of rheumatoid arthritis (RA) and spondyloarthritis (SpA) in Turkey using the same telephone questionnaire developed for screening RA and SpA in France and used in Serbia and Lithuania.

Material and methods: The study was performed in two steps. In step I, the French questionnaire was translated into Turkish and validated through a group of 200 patients ( 80 males, 120 females; mean age $44.0 \pm 13.1$ years; range, 19 to 75 years) followed up at the rheumatology departments of University Hospitals in Antalya and Ankara. In step II, the validated Turkish questionnaire was administered face-to-face to randomly selected 4,012 subjects ( 1,670 males, 2,342 females; mean age $41.5 \pm 16.8$ years; range, 16 to 97 years) by trained general practitioners across the country, in 25 provinces for case detection. The subjects who were suspected of having RA or SpA in accordance with the questionnaire were invited to the nearest university hospital for rheumatologic examination in order to confirm the diagnosis.

Results: In step II, a total of 25 subjects ( 2 males, 23 females) were diagnosed as RA. The standardized RA prevalence for the general population of Turkey was calculated as $0.56 \%$ (95\% confidence interval [Cl]; 0.33-0.79), $0.10 \%$ (95\% $\mathrm{Cl} ;-0.05-0.25)$ for males and $0.89 \%$ (95\% Cl; $0.51-1.27)$ for females. A total of 18 subjects ( 3 males, 15 females) were diagnosed as SpA. The standardized SpA prevalence for the general population of Turkey was $0.46 \%$ $(95 \% \mathrm{Cl} ; 0.25-0.67), 0.17 \%(95 \% \mathrm{Cl} ;-0.03-0.37)$ for males and $0.65 \%$ (95\% Cl; 0.32-0.98) for females. The prevalence of RA was highest in the Northern region (2.00\%) and the prevalence of SpA was highest in the Central region (1.49\%).

Conclusion: The prevalences of RA and SpA in Turkey are close to each other and there are significant inter-regional variations in prevalences of both RA and SpA.

Keywords: Epidemiology; prevalence; rheumatoid arthritis; spondyloarthritis.
\end{abstract}

Received: April 21, 2017 Accepted: July 11, 2017 Published online: October 13, 2017

Correspondence: Tiraje Tuncer, MD. Akdeniz Üniversitesi Tıp Fakültesi Fiziksel Tıp ve Rehabilitasyon Anabilim Dalı, 07070 Konyaaltı, Antalya, Turkey.

Tel: +90 242 - 2496681 e-mail: tirajetuncer@akdeniz.edu.tr

@2018 Turkish League Against Rheumatism. All rights reserved. 
Rheumatoid arthritis (RA) and spondyloarthritis (SpA) are the most common inflammatory arthropathies in adults. RA is a systemic, autoimmune, inflammatory disease primarily affecting the peripheral synovial joints. Owing to progressive joint damage, it may result in functional impairment and disability. SpAs are a group of rheumatic diseases including ankylosing spondylitis (AS), psoriatic arthritis, reactive arthritis and enteropathic arthropathies. In developed countries, a large number of publications are available on the prevalence of RA and SpA., However, in low- and middle-income countries, studies on RA and SpA are sparse. Likewise, in Turkey, epidemiological studies regarding RA and $\mathrm{SpA}$ reported to date are very few and regional, rather than nationwide. ${ }^{3-5}$

After a survey, a telephone questionnaire developed for screening RA and SpA was validated and used for several surveys in France. ${ }^{6-10}$ Given the French experience and the support of the European League Against Rheumatism (EULAR), it became possible to carry out similar studies across Europe using the same methodology. In this way, the aforementioned telephone questionnaire was adapted to and validated in Serbian and Lithuanian, and also used in a prevalence survey carried out in Lithuania ${ }^{11,12}$ and Serbia. ${ }^{13}$ Our study was based on the same questionnaire and endorsed by EULAR and the Turkish League Against Rheumatism. To the best of our knowledge, this is the first nationwide epidemiological study to estimate the prevalence of RA and SpA in Turkey. Therefore, in this article, we aimed to estimate the prevalence of $\mathrm{RA}$ and $\mathrm{SpA}$ in Turkey using the same telephone questionnaire developed for screening $\mathrm{RA}$ and $\mathrm{SpA}$ in France and used in Serbia and Lithuania.

\section{MATERIAL AND METHODS}

This study was conducted in two steps: in the first step the aforementioned French questionnaire was translated into Turkish and validated through a group of patients followed up at the rheumatology departments of Akdeniz University Hospital (Antalya), and of Ankara University Hospital (Ankara). In step II, the validated Turkish version was used in a nationwide survey to detect the prevalence of $\mathrm{RA}$ and $\mathrm{SpA}$ in 25 provinces of
Turkey. The study was conducted in accordance with the principles of the Declaration of Helsinki.

\section{Step I}

The original French questionnaire, which comprised 33 items covering signs, symptoms, self-reported diagnosis and classification criteria for RA (American College of Rheumatology [ACR] 1987) ${ }^{14}$ and SpA (The European Spondylarthropathy Study Group [ESSG] 1991), ${ }^{15}$ was translated into Turkish using the standard methodology of forward then backward translations and expert committee decision making. ${ }^{16} 200$ patients were included in the study (80 males, 120 females; mean age 44.0 13.1 years; range, 19 to 75 years). The questionnaire's validity was tested by administering it to the subjects, divided into four groups: (i) patients with RA, (ii) patients with SpA, (iii) patients with diagnoses of non-inflammatory musculoskeletal diseases such as osteoarthritis, osteoporosis, fibromyalgia, disc herniation, spondylosis and non-specific mechanical low back pain, and (iv) controls. All patients were recruited from the hospital registries of Akdeniz University and of Ankara University, and controls were selected from the general population using randomly sampled telephone numbers. All patients with RA and SpA were also required to fulfill ACR 1987 and ESSG 1991 classification criteria, respectively. Two certified rheumatologists and two physiatrists experienced in rheumatic diseases ascertained the patients' clinical diagnoses and documented their findings on standard forms. All the subjects were interviewed by telephone by a trained layperson who was unaware of the patients' diagnoses. Subjects who did not answer the telephone were reached by subsequent calls.

\section{Step II}

Turkey is a country divided into seven geographical regions (the Aegean [the Western], the Marmara [the Northwestern], the Mediterranean [the Southern], the Black Sea [the Northern], the Central, the Eastern, and the Southeastern) and 81 administrative provinces. Its population derived from the national census data was 67.8 million in $2000 .{ }^{17}$

In step II, the validated Turkish questionnaire was administered face-toface to randomly selected 4,012 subjects 
(1,670 males, 2,342 females; mean age $41.5 \pm 16.8$ years; range, 16 to 97 years) by 20 trained general practitioners across the country for case detection. For randomization process, a two-stage cluster sampling method was used (Table 1). The first stage corresponded to all the seven geographical regions mentioned above and the second stage to 25 provinces: Adana, Afyon(karahisar), Ankara, Antalya, Aydin, Bursa, Denizli, Diyarbakır, Edirne, Elazığ, Erzurum, Gaziantep, Isparta, İstanbul, İzmir, Kayseri, Kırıkkale, Kocaeli, Konya, Malatya, Manisa, Mersin, Samsun, Sivas, and Van (Figure 1). Two levels of either urban or rural settlement type defined the second stage. Urban clusters were selected by the proportional sampling method using zip codes and the rural clusters were sampled from the lists of villages not further than $80 \mathrm{~km}$ from the relevant provincial city center. The number of clusters was determined in proportion to the size of the urban and rural population of the relevant province. For intra-cluster sampling, a quota sampling method was used to determine the appropriate number of subjects according to the age and sex. The interviewer chose any street from the sampled zip code by his own will and started the interviews beginning from the first block on the right side of the street in the urban settlements or beginning from the first house on the right side of the reeve's office in the rural settlements until he/she completed the predetermined cluster size. Inclusion criteria for the study were as follows: being 16 years of age or over, giving oral consent to participate in the screening, and being a citizen of Turkey. All the subjects belonging to the household and present on site during the screening were interviewed, but those who were cognitively impaired or unable to understand the questions, or unable to give clear answers were excluded. Any present visitors not belonging to the household but belonging to the same cluster were included; otherwise, they were excluded.

The diagnostic procedure was carried out according to the algorithm suggested by the questionnaire itself. For case confirmation, the subjects who were suspected of having RA or SpA in accordance with the questionnaire were invited to the nearest university hospital to be examined by a rheumatologist or a physiatrist experienced
Table 1. Procedure of sampling and randomization in step II

\section{A. Sampling}

1. First stage: Determining of urban and rural sample sizes for all seven geographical regions

\begin{tabular}{lcc} 
& \multicolumn{2}{c}{ Sample size* $(\mathrm{n})$} \\
\cline { 2 - 3 } Region & Urban & Rural \\
\hline Northwestern & 810 & 220 \\
Northern & 240 & 250 \\
Western & 330 & 210 \\
Central & 480 & 210 \\
Eastern & 200 & 170 \\
Southern & 310 & 200 \\
Southeastern & 110 & 100
\end{tabular}

2. Second stage: Determining of urban and rural sample sizes for selected 25 provinces

\begin{tabular}{lcc} 
& \multicolumn{2}{c}{ Sample size $^{*}(\mathrm{n})$} \\
\cline { 2 - 3 } Region & Urban & Rural \\
\hline Adana & 120 & 40 \\
Afyon & 30 & 40 \\
Ankara & 270 & 50 \\
Antalya & 80 & 80 \\
Aydın & 30 & 40 \\
Bursa & 110 & 50 \\
Denizli & 30 & 40 \\
Diyarbakır & 110 & 100 \\
Edirne & 20 & 20 \\
Elazığ & 40 & 30 \\
Erzurum & 60 & 50 \\
Gaziantep & 130 & 50 \\
Isparta & 30 & 20 \\
İstanbul & 630 & 100 \\
İzmir & 190 & 50 \\
Kayseri & 60 & 30 \\
Kirkkale & 20 & 10 \\
Kocaeli & 50 & 50 \\
Konya & 100 & 90 \\
Malatya & 50 & 40 \\
Manisa & 50 & 40 \\
Mersin & 80 & 60 \\
Samsun & 240 & 250 \\
Sivas & 30 & 30 \\
Van & 50 & 50 \\
Ran & &
\end{tabular}

\section{B. Randomization}

1. Randomizing the urban settlements from the list of zip code and rural settlements from the list of villages not further than $80 \mathrm{~km}$ from the provincial center.

2. Performing the interviews beginning from the first block located on the right side of the selected any street by the interviewer belonging to the randomized zip code in the urban settlements and beginning from the first house on the right side of the reeve's house in the rural settlements.

3. Terminating the interviews when the number of performed interviews reached the predetermined cluster size (10-20) for that zip code or village.

"Numbers were rounded to the nearest ten.

in rheumatic diseases and, if needed, to undergo some laboratory and/or X-ray investigations to confirm the diagnosis. 


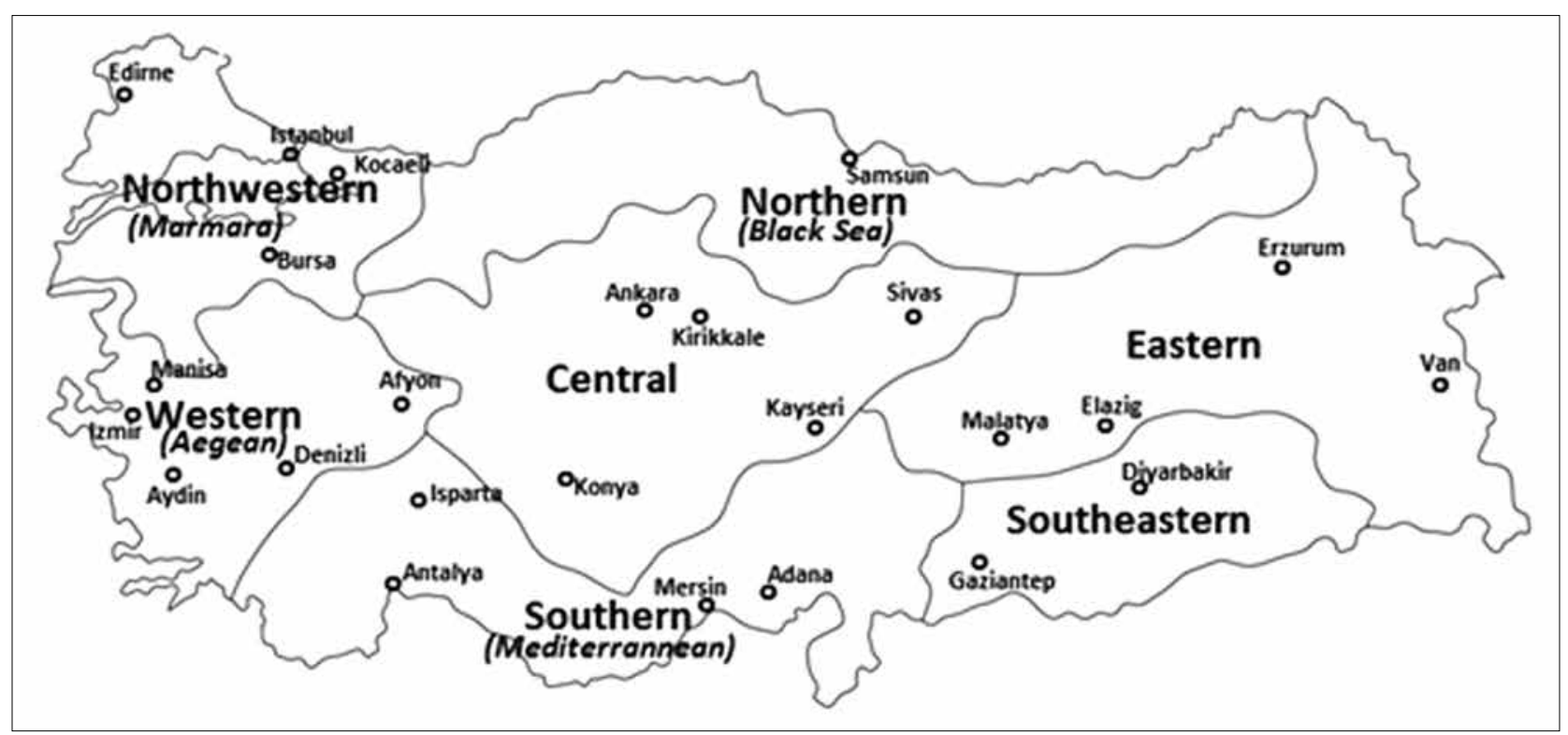

Figure 1. Regions of Turkey and provinces selected for the study.

\section{Statistical analysis}

\section{Step I}

The sensitivity and specificity were calculated for each item of the questionnaire, separately and in combination, in reference to the clinical diagnosis and the classification criteria. Statistical analysis for step I was performed using SAS $^{\circledR} 8.0$ statistical software.

\section{Step II}

We found that at least 3,984 individuals needed to be included in our study, for an estimated prevalence of 0.03 and precision level of 0.01 , corrected by a 1.6-fold increase for the impact of design at an $\alpha$ error level of 0.05 . Using the direct standardization method, the prevalence estimates were adjusted for age and sex to Turkey's population based on the data obtained in the 2000 Turkish national census. The 95\% confidence intervals (CIs) were calculated as suggested. ${ }^{18}$ Odds ratios and 95\% Cls for regional variation of standardized prevalence estimates were obtained using MedCalc ${ }^{\circledR}$ statistical software version 17.6 (MedCalc Software buba, Ostend, Belgium).

\section{RESULTS}

Of a total of 200 subjects recruited in step I, 52 (6 males, 46 females) had RA, 49 (42 males,
7 females) had SpA, 49 (11 males, 38 females) had non-inflammatory musculoskeletal diseases, and 50 (21 males, 29 females) were controls. The mean age of patients with RA, SpA, non-inflammatory musculoskeletal diseases, and controls were $52.6 \pm 10.0,39.6 \pm 10.8,49.7 \pm 10.0$ and $34.2 \pm 12.4$ years, respectively. All of the subjects were contacted by telephone and they responded to the questionnaire. When the clinical diagnosis was taken as the standard, sensitivity of the items on the questionnaire ranged from $94 \%$ to $0 \%$ in RA, and from $90 \%$ to $2 \%$ in SpA (Table 2).

The distribution of the study sample and Turkey's population by age and sex were shown in Table 3. In step II, a total of 25 subjects (2 males, 23 females) were diagnosed as RA (Table 4). The mean age of males and females with RA was 49.0 \pm 11.3 years (range, 41-57 years) and $46.5 \pm 15.0$ years (range, 20-70 years), respectively. The crude prevalence for RA was $0.62 \%(95 \% \mathrm{CI} ; 0.38-0.86)$ in general, $0.12 \%$ (95\% CI; -0.05-0.29) for males and 0.98\% (95\% CI; 0.58-1.38) for females.

The standardized RA prevalence for the general population of Turkey was calculated as $\quad 0.56 \% \quad(95 \% \quad \mathrm{CI} ; \quad 0.33-0.79), \quad 0.10 \%$ (95\% CI; $-0.05-0.25)$ for males and $0.89 \%$ (95\% CI; 0.51-1.27) for females (Table 5). 


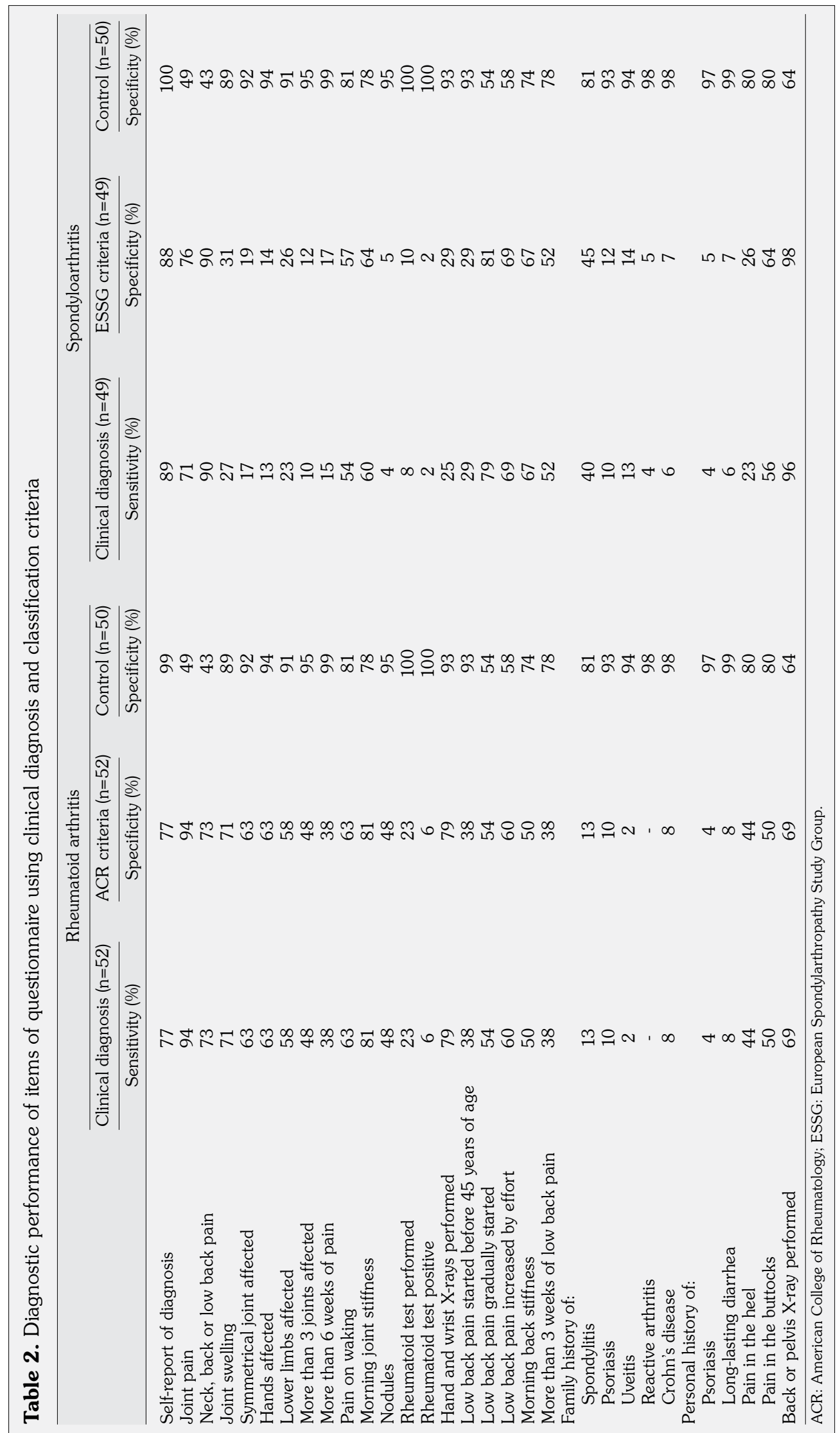


Table 3. Age and sex distribution of study sample and Turkey's population

\begin{tabular}{|c|c|c|c|c|c|c|c|c|}
\hline \multirow{3}{*}{ Age (year) } & \multicolumn{4}{|c|}{ Study sample } & \multicolumn{4}{|c|}{ Turkey's population } \\
\hline & \multicolumn{2}{|c|}{ Female } & \multicolumn{2}{|c|}{ Male } & \multicolumn{2}{|c|}{ Female } & \multicolumn{2}{|c|}{ Male } \\
\hline & $\mathrm{n}$ & $\%$ & $\mathrm{n}$ & $\%$ & $\mathrm{n}$ & $\%$ & $\mathrm{n}$ & $\%$ \\
\hline $16-24$ & 419 & 17.9 & 302 & 18.1 & 6093983 & 26.5 & 6382124 & 27.6 \\
\hline $25-34$ & 546 & 23.3 & 355 & 21.3 & 5376110 & 23.4 & 5528800 & 23.9 \\
\hline $35-44$ & 463 & 19.8 & 341 & 20.4 & 4386033 & 19.1 & 4537110 & 19.6 \\
\hline $45-54$ & 374 & 16.0 & 273 & 16.3 & 3018970 & 13.1 & 3067148 & 13.3 \\
\hline $55-64$ & 254 & 10.8 & 198 & 11.9 & 2007157 & 8.7 & 1880553 & 8.1 \\
\hline $65-74$ & 209 & 8.9 & 132 & 7.9 & 1505409 & 6.5 & 1312751 & 5.7 \\
\hline$\geq 75$ & 77 & 3.3 & 69 & 4.1 & 603977 & 2.6 & 436812 & 1.9 \\
\hline Total & 2342 & 100.0 & 1670 & 100.0 & 22991639 & 100.0 & 23145298 & 100.0 \\
\hline
\end{tabular}

Table 4. Distribution of cases by age group and sex

\begin{tabular}{|c|c|c|c|c|c|c|c|c|c|c|c|c|c|c|}
\hline \multirow{3}{*}{ Age (year) } & \multicolumn{6}{|c|}{ Cases with rheumatoid arthritis } & \multicolumn{6}{|c|}{ Cases with spondyloarthritis } & \multirow{2}{*}{\multicolumn{2}{|c|}{$\frac{\text { Study sample }}{\text { Total }}$}} \\
\hline & \multicolumn{2}{|c|}{ Female } & \multicolumn{2}{|c|}{ Male } & \multicolumn{2}{|c|}{ Total } & \multicolumn{2}{|c|}{ Female } & \multicolumn{2}{|c|}{ Male } & \multicolumn{2}{|c|}{ Total } & & \\
\hline & $\mathrm{n}$ & $\%$ & $\mathrm{n}$ & $\%$ & $\mathrm{n}$ & $\%$ & $\mathrm{n}$ & $\%$ & $\mathrm{n}$ & $\%$ & $\mathrm{n}$ & $\%$ & $\mathrm{n}$ & $\%$ \\
\hline $16-24$ & 1 & 0.14 & - & - & 1 & 0.14 & 2 & 0.28 & - & - & 2 & 0.28 & 721 & 100.00 \\
\hline $25-34$ & 5 & 0.55 & - & - & 5 & 0.55 & 6 & 0.67 & 1 & 0.11 & 7 & 0.78 & 901 & 100.00 \\
\hline $35-44$ & 5 & 0.62 & 1 & 0.12 & 6 & 0.75 & 4 & 0.50 & 1 & 0.12 & 5 & 0.62 & 804 & 100.00 \\
\hline $45-54$ & 5 & 0.77 & - & - & 5 & 0.77 & 2 & 0.31 & 1 & 0.15 & 3 & 0.46 & 647 & 100.00 \\
\hline $55-64$ & 4 & 0.88 & 1 & 0.22 & 5 & 1.11 & 1 & 0.22 & - & - & 1 & 0.22 & 452 & 100.00 \\
\hline $65-74$ & 3 & 0.88 & - & - & 3 & 0.88 & - & - & - & - & - & - & 341 & 100.00 \\
\hline$\geq 75$ & - & - & - & - & - & - & - & - & - & - & - & - & 146 & 100.00 \\
\hline Total & 23 & 0.57 & 2 & 0.05 & 25 & 0.62 & 15 & 0.37 & 3 & 0.07 & 18 & 0.45 & 4012 & 100.00 \\
\hline
\end{tabular}

The highest prevalence of RA was in the age group of 55-64 years (1.11\%) (Table 4). The prevalence of RA was highest in the Northern region $(2.00 \%)$ indicating a significant regional difference ( $p=0.003$, Table 6).
A total of 18 subjects (3 males, 15 females) were diagnosed as SpA (Table 4). The mean age was 38.0 \pm 11.4 years (range, 25-46 years) for males and $36.7 \pm 11.2$ years (range, 23-62 years) for females. The crude weighted prevalence for

Table 5. Standardized prevalence of rheumatoid arthritis and spondyloarthritis in overall population of Turkey aged 16 or over

\begin{tabular}{lcccccr}
\hline & Total (\%) & $95 \%$ CI & Female & $95 \%$ CI & Male & $95 \%$ CI \\
\hline Rheumatoid arthritis & 0.56 & $0.33-0.79$ & 0.89 & $0.51-1.27$ & 0.10 & $-0.02-0.38$ \\
Spondyloarthritis & 0.46 & $0.25-0.67$ & 0.65 & $0.32-0.98$ & 0.17 & $-0.03-0.37$ \\
\hline CI: Confidence interval. & & & & & \\
\hline
\end{tabular}

Table 6. Crude and standardized prevalence of rheumatoid arthritis in regions of Turkey

\begin{tabular}{|c|c|c|c|c|c|c|c|c|}
\hline \multirow[t]{2}{*}{ Region } & \multirow{2}{*}{$\frac{\text { Sample }}{\mathrm{n}}$} & \multicolumn{2}{|c|}{ Crude } & \multicolumn{4}{|c|}{ Standardized } & \multirow[b]{2}{*}{$p$} \\
\hline & & $\%$ & $95 \% \mathrm{CI}$ & $\%$ & $95 \% \mathrm{CI}$ & OR & $95 \% \mathrm{CI}$ & \\
\hline Northwestern & 1,027 & 0.29 & $-0.04-0.62$ & 0.25 & $-0.06-0.56$ & 1.0 & & \\
\hline Northern & 490 & 2.04 & $0.79-3.29$ & 2.00 & $0.76-3.24$ & 7.1 & $1.9-26.0$ & 0.003 \\
\hline Western & 540 & 0.56 & $-0.07-1.19$ & 0.53 & $-0.08-1.14$ & 1.9 & 0.4-9.5 & 0.430 \\
\hline Central & 689 & 0.87 & $0.18-1.56$ & 0.72 & $0.09-1.35$ & 2.5 & $0.6-10.5$ & 0.212 \\
\hline Eastern & 368 & 0.27 & $-0.26-0.80$ & 0.32 & $-0.26-0.90$ & 0.9 & $0.1-9.0$ & 0.950 \\
\hline Southern & 509 & 0.39 & $-0.15-0.93$ & 0.31 & $-0.17-0.79$ & 1.3 & $0.2-8.1$ & 0.745 \\
\hline Southeastern & 389 & 0 & 0 & 0 & 0 & 0.4 & $0.0-7.3$ & 0.518 \\
\hline
\end{tabular}


Table 7. Crude and standardized prevalence of spondyloarthritis in regions of Turkey

\begin{tabular}{|c|c|c|c|c|c|c|c|c|}
\hline \multirow[t]{2}{*}{ Region } & \multirow{2}{*}{$\frac{\text { Sample }}{\mathrm{n}}$} & \multicolumn{2}{|c|}{ Crude } & \multicolumn{4}{|c|}{ Standardized } & \multirow[b]{2}{*}{$p$} \\
\hline & & $\%$ & $95 \% \mathrm{CI}$ & $\%$ & $95 \% \mathrm{CI}$ & OR & $95 \% \mathrm{CI}$ & \\
\hline Northwestern & 1,027 & 0.10 & $-0.09-0.29$ & 0.18 & $-0.08-0.44$ & 1.0 & & \\
\hline Northern & 490 & 0.61 & $-0.08-1.30$ & 0.78 & $0.00-1.56$ & 4.2 & $0.8-23.1$ & 0.097 \\
\hline Western & 540 & 0.37 & $-0.14-0.88$ & 0.34 & $-0.15-0.83$ & 1.9 & $0.3-13.6$ & 0.520 \\
\hline Central & 689 & 1.45 & $0.56-2.34$ & 1.49 & $0.59-2.39$ & 7.5 & $1.6-34.6$ & 0.009 \\
\hline Eastern & 368 & 0.54 & $-0.21-1.29$ & 0.53 & $-0.21-1.27$ & 2.8 & $0.4-20.0$ & 0.304 \\
\hline Southern & 509 & 0 & 0 & 0 & 0 & 0.4 & $0.0-8.4$ & 0.557 \\
\hline Southeastern & 389 & 0 & 0 & 0 & 0 & 1.0 & $0.8-23.1$ & 0.679 \\
\hline
\end{tabular}

SpA was $0.45 \%(95 \% \mathrm{CI}$; 0.24-0.66) in general, $0.18 \%$ (95\% CI; $-0.02-0.38$ ) for males and $0.64 \%$ (95\% CI; 0.32-0.96) for females.

The standardized SpA prevalence for the general population of Turkey was calculated as $0.46 \% \quad(95 \% \quad \mathrm{CI} ; \quad 0.25-0.67), \quad 0.17 \%$ $(95 \% \mathrm{CI} ;-0.03-0.37)$ for males and $0.65 \%$ (95\% CI; 0.32-0.98) for females (Table 5). The highest prevalence of $\mathrm{SpA}$ was in the age group of 25-34 years $(0.78 \%)$ (Table 4$)$. The prevalence of SpA was highest in the central region (1.49\%) pointing to a significant regional difference $(p=0.009)$ (Table 7).

\section{DISCUSSION}

To the best of our knowledge, this is the first nationwide survey showing the estimates of prevalence of RA and SpA in Turkey. Previous epidemiological studies on RA and SpA in Turkey were carried out in just one urban metropolitan area, i.e. Antalya ${ }^{4}$ or in a few urban quarters not representing the whole metropolitan area, i.e. İzmir ${ }^{3,5}$ or in a few regional small urban areas, i.e. the eastern Black Sea region ${ }^{19}$ or in an urban and rural area of a small town, i.e. Havsa. ${ }^{20}$ All of these studies were performed using face-to-face questionnaires. Of those, three used cluster sampling, ${ }^{3-5}$ one intended to reach the entire population living in the study area ${ }^{20}$ and one did not mention how the sampling procedure was managed. ${ }^{19}$ Four of those studies were held mainly in coastal urban areas, ${ }^{3-5,19}$ not taking into consideration the hinterland and rural areas. Therefore, our study had the advantage of covering both urban and rural areas and also inland Turkey.
We used a questionnaire endorsed by EULAR, which was also used in France, Lithuania and Serbia, $, 10,12,13$ providing a reliable opportunity to compare the differences between countries. However, we used it in face-to-face interviews unlike the telephone interviews employed in France, Lithuania and Serbia, because neither the landline phones nor the mobile phones were in use in some rural areas of Turkey and landline phones where available in Turkey were largely being replaced by mobile phones at the time the survey was carried out. In doing so, we aimed to capture all the individuals intended to be involved in the study. Thus, despite being less costly than face-to-face surveys, telephone surveys might result in lower response rates. ${ }^{21}$

Our study indicates a prevalence of $0.56 \%$ for $\mathrm{RA}$ adjusted for the general population aged 16 or over. In previous studies, the prevalence of RA adjusted for the general population aged 20 or over of Turkey was estimated as $0.32 \%, 0.36 \%$, $0.42 \%$ and $1.01 \%$ in Havsa, İzmir, Antalya and the eastern Black Sea region, respectively. 3,4,19,20 Those studies indicate that RA prevalence shows regional variations in Turkey. Indeed, our study has also shown that there are regional variations in the prevalence of RA. The prevalence of RA was highest in the Northern region (2.04\%) and lowest in the Southeastern region (0\%).

Our study showed a prevalence of $0.46 \%$ for $\mathrm{SpA}$ adjusted for the general population aged 16 or over. As expected, prevalence of SpA was highest in the age group of 25-34 years (1.28\%). The prevalence of SpA was also heterogeneous among regions as of $\mathrm{RA}$, being significantly highest in the Central region (1.45\%). Interregional variations in prevalence of $\mathrm{SpA}$ were also shown in previous studies. ${ }^{22-24}$ The prevalence of SpA 
shows correlations with the prevalence of human leukocyte antigen B27 (HLA-B27). ${ }^{24}$ According to two small non-population based studies, -one from the West and the other from the East of Turkey- the frequency of HLA-B27 varies between $2.8 \%$ and $11.1 \%$ in Turkey. ${ }^{25,26}$ This considerably broad range of HLA-B27 frequency suggests an apparent interregional variation in the prevalence of $\mathrm{SpA}$. However, we are not sure whether the heterogeneity of regional prevalence of $\mathrm{SpA}$ in Turkey can be explained by HLA-B27 frequency, as no nationwide data exist on the prevalence of HLA-B27. At present, regarding the paucity of data, we cannot rule out the environmental risk factors for heterogeneity of the prevalence of SpA as well.

On the other hand, we found a higher prevalence of $\mathrm{SpA}$ in females compared to males $(0.65 \%$ vs. $0.17 \%$, respectively). Interestingly, in a previous regional prevalence study performed in Turkey, the prevalence of SpA was also higher in females than in males $(1.22 \%$ vs. $0.88 \%$, respectively). ${ }^{5}$ In that study, it was shown that the overall prevalence of SpA (1.05\%) was even higher than of RA. A previous study conducted in Canada revealed that male/female prevalence ratio of AS decreased from 1.70 in 1995 to 1.21 by 2010 and the prevalence of AS tripled over the past two decades. ${ }^{27}$ This suggests that both the prevalence of $\mathrm{SpA}$ and the proportion of female patients with SpA might be increasing in other parts of the world as well, which may be due to the increasing awareness of $\mathrm{SpA}$ in recent years.

We detected no case of RA or SpA in the Southeastern region. This could be partly explained by the region itself, containing one of the smallest populations in the survey. It is hard to establish a conclusion, since no prevalence study conducted in this region exists, which would support this result. Further regional studies using the same methodology related to the prevalence of RA and $\mathrm{SpA}$ are required to assist us in understanding the genetic and environmental factors.

Our study has some limitations. Face-to-face interviews might have their own limitations such as encountering more females than males in households, since the labor force is overwhelmingly comprised of males in Turkey, rendering the females mostly homemakers. Accordingly, 58\% of the individuals involved in our study were females whereas the national census performed in 2000 showed that females constituted 50\% of Turkey's population. The rate of females was even higher $(61 \%)$ in the Northern region where the prevalence of RA was highest. This could be a bias for the higher prevalence of RA as it is known that RA is mostly seen in females. However, in the Lithuanian study in which the same methodology (by telephone) was used, the authors emphasized the same problem. ${ }^{12}$ Another limitation of our study was not studying the HLA-B27.

In conclusion, our study showed that a northsouth gradient of RA across Europe might not exist, compared to the prevalence reported from Northern European countries. ${ }^{12,28}$ However, a north-south gradient of RA might exist in Turkey. Regarding SpA, the proportion of female patients may be higher than expected while there are interregional differences in the prevalence of SpA.

\section{Declaration of conflicting interests}

The authors declared no conflicts of interest with respect to the authorship and/or publication of this article.

\section{Funding}

This survey was supported with an unconditional Grant to Turkish League Against Rheumatism from Sanofi Health Products Company (former Aventis), Turkey. The secretary expenses was covered by EULAR Standing Committee on Epidemiology and Health Services Research.

\section{REFERENCES}

1. Silman AJ, Pearson JE. Epidemiology and genetics of rheumatoid arthritis. Arthritis Res 2002;4:265-72.

2. Stolwijk C, Boonen A, van Tubergen A, Reveille JD. Epidemiology of spondyloarthritis. Rheum Dis Clin North Am 2012;38:441-76.

3. Akar S, Birlik M, Gurler O, Sari I, Onen F, Manisali $\mathrm{M}$, et al. The prevalence of rheumatoid arthritis in an urban population of Izmir-Turkey. Clin Exp Rheumatol 2004;22:416-20.

4. Kaçar C, Gilgil E, Tuncer T, Bütün B, Urhan S, Arikan $\mathrm{V}$, et al. Prevalence of rheumatoid arthritis in Antalya, Turkey. Clin Rheumatol 2005;24:212-4.

5. Onen F, Akar S, Birlik M, Sari I, Khan MA, Gurler O, et al. Prevalence of ankylosing spondylitis and related spondyloarthritides in an urban area of Izmir, Turkey. J Rheumatol 2008;35:305-9.

6. Guillemin F, Saraux A, Guggenbuhl P, Roux $\mathrm{CH}$, Fardellone $\mathrm{P}$, Le Bihan $\mathrm{E}$, et al. Prevalence of 
rheumatoid arthritis in France: 2001. Ann Rheum Dis 2005;64:1427-30.

7. Guillemin F, Saraux A, Fardellone P, Guggenbuhl P, Behier JM, Coste J. Detection of cases of inflammatory rheumatic disorders: performance of a telephone questionnaire designed for use by patient interviewers. Ann Rheum Dis 2003;62:957-63.

8. Saraux A, Guillemin F, Fardellone P, Guggenbuhl P, Behier JM, Cantagrel A, et al. Agreement between rheumatologist visit and lay interviewer telephone survey for screening for rheumatoid arthritis and spondyloarthropathy. Joint Bone Spine 2004;71:44-50.

9. Guillemin F, Saraux A, Guggenbuhl P, Roux $\mathrm{CH}$, Fardellone $\mathrm{P}$, Le Bihan E,et al. Prevalence of rheumatoid arthritis in France: 2001. Ann Rheum Dis 2005;64:1427-30.

10. Saraux A, Guillemin F, Guggenbuhl P, Roux CH, Fardellone $\mathrm{P}$, Le Bihan $\mathrm{E}$, et al. Prevalence of spondyloarthropathies in France:2001. Ann Rheum Dis 2005;64:1431-5.

11. Zlatkovic-Svenda MI, Stojanovic RM, Milenkovic MP, Vlajinac HD, Le Bihan E, Guillemin F. Adaptation and validation of a telephone questionnaire--Serbian version for case detection of rheumatoid arthritis and spondyloarthropathy (multicentric Eular study). Clin Exp Rheumatol 2007;25:75-84.

12. Adomaviciute $\mathrm{D}$, Pileckyte $\mathrm{M}$, Baranauskaite $\mathrm{A}$, Morvan J, Dadoniene J, Guillemin F. Prevalence survey of rheumatoid arthritis and spondyloarthropathy in Lithuania. Scand J Rheumatol 2008;37:113-9. Erratum in: Scand J Rheumatol 2009;38:76.

13. Zlatkovic-Svenda MI, Stojanovic RM, B SipeticGrujicic S, Guillemin F. Prevalence of rheumatoid arthritis in Serbia. Rheumatol Int 2014;34:649-58.

14. Arnett FC, Edworthy SM, Bloch DA, McShane DJ, Fries JF, Cooper NS, et al. The American Rheumatism Association 1987 revised criteria for the classification of rheumatoid arthritis. Arthritis Rheum 1988;31:315-24.

15. Dougados $M$, van der Linden $S$, Juhlin $R$, Huitfeldt B, Amor B, Calin A, et al. The European Spondylarthropathy Study Group preliminary criteria for the classification of spondylarthropathy. Arthritis Rheum 1991;34:1218-27.

16. Guillemin F, Bombardier C, Beaton D. Cross-cultural adaptation of health-related quality of life measures: literature review and proposed guidelines. J Clin Epidemiol 1993;46:1417-32.
17. 2000 Census of Population. T.C. Başbakanlık Devlet İstatistik Enstitüsü. Ankara: 2000.

18. Riffenburgh RH. Confidence Intervals. In: Statistics in Medicine. London: Academic Press; 2012. p.146-9.

19. Capkin E, Cakirbay H, Karkucak M, Topbas M, Serdaroğlu M, Guler M, et al. Prevalence of rheumatoid arthritis in the eastern Black Sea region of Turkey. Int J Rheum Dis 2010;13:380-4.

20. Cakır N, Pamuk ÖN, Derviş E, Imeryüz N, Uslu H, Benian Ö, et al. The prevalences of some rheumatic diseases in western Turkey: Havsa study. Rheumatol Int 2012;32:895-908.

21. Siemiatycki J. A comparison of mail, telephone, and home interview strategies for household health surveys. Am J Public Health 1979;69:238-45.

22. Roux $\mathrm{CH}$, Saraux $\mathrm{A}$, Le Bihan $\mathrm{E}$, Fardellone P, Guggenbuhl P, Fautrel B, et al. Rheumatoid arthritis and spondyloarthropathies: geographical variations in prevalence in France. $\mathrm{J}$ Rheumatol 2007;34:117-22.

23. Hukuda S, Minami M, Saito T, Mitsui H, Matsui N, Komatsubara Y, et al. Spondyloarthropathies in Japan: nationwide questionnaire survey performed by the Japan Ankylosing Spondylitis Society. J Rheumatol 2001;28:554-9.

24. Exarchou S, Lindström U, Askling J, Eriksson JK, Forsblad-d'Elia H, Neovius M, et al. The prevalence of clinically diagnosed ankylosing spondylitis and its clinical manifestations: a nationwide register study. Arthritis Res Ther 2015;17:118.

25. Uyar FA, Dorak MT, Saruhan-Direskeneli G. Human leukocyte antigen-A, -B and -C alleles and human leukocyte antigen haplotypes in Turkey: relationship to other populations. Tissue Antigens 2004;64:180-7.

26. Pirim I, Atasoy M, Ikbal M, Erdem T, Aliagaoglu C. HLA class I and class II genotyping in patients with Behcet's disease: a regional study of eastern part of Turkey. Tissue Antigens 2004;64:293-7.

27. Haroon NN, Paterson JM, Li P, Haroon N. Increasing proportion of female patients with ankylosing spondylitis: a population-based study of trends in the incidence and prevalence of AS. BMJ Open 2014;15;4:6634.

28. Simonsson M, Bergman S, Jacobsson LT, Petersson IF, Svensson B. The prevalence of rheumatoid arthritis in Sweden. Scand J Rheumatol 1999;28:340-3. 